\title{
Reproductive Indexes: All are Important but some are More Relevant than Others
}

\author{
Rafael Herrera Alvarez RH* \\ Agency for Agribusiness Technology of São Paulo, Brazil
}

Submission: April 13, 2017; Published: April 27, 2017

*Corresponding author: Rafael Herrera Alvarez, Agency for Agribusiness Technology of São Paulo, São Paulo State, Brazil, Email: rherrera@apta.sp.gov.br

\section{Abstract}

Reproduction is a fundamental part of the productive process of cattle herds, since it provides the raw material (calves, milk) that makes the livestock industry be a profitable business. For this reason, actions that aim to improve the reproductive efficiency should be constantly evaluated in order to, if necessary, adopt new corrective strategies. This article suggests the pregnancy rate as the most relevant index to be considered in order to make timely and accurate management decisions to improve the reproductive performance.

Keywords: Pregnancy rate; Calving interval; Conception rate; Dairy cattle

\section{Introduction}

Probably, the calving's interval is the most used parameter to measure the reproductive efficiency of dairy herds [1,2]. As its name suggests, it expresses the interval between two consecutive calving's of the same cow. In general, an interval of about 12 months is considered an ideal index of performance (Table 1).

Table 1: Interval between calving and production efficiency of dairy herds in Brazil [3].

\begin{tabular}{|c|c|c|}
\hline \multirow{2}{*}{ Parameters } & \multicolumn{2}{|c|}{ Interval Between Calving } \\
\cline { 2 - 3 } & $\mathbf{1 2}$ months & 18 months \\
\hline Cow lifespan & 6 years & 6 years \\
\hline № of calves & 6 & 4 \\
\hline Lactation production & $3500 \mathrm{~kg}$ & $3500 \mathrm{~kg}$ \\
\hline Lifespan production & $21000 \mathrm{~kg}$ & $14000 \mathrm{~kg}$ \\
\hline Cow production / day & $9.6 \mathrm{~kg}$ & $6.4 \mathrm{~kg}$ \\
\hline Daily loss / cow & & $3.2 \mathrm{~kg}$ \\
\hline
\end{tabular}

However, for some researchers, this indicator has several flaws and, therefore, should not be used as a management tool for monitoring reproductive efficiency. The main limitation is the delay in obtaining the index. Indeed, to calculating it the cow must have calved twice consecutively. When a problem is identified through this index, it means that the problem happened for at least 9 to 12 months before, that is, actions to correct the problem should have been taken a long time ago. In addition, it does not include the primiparous (first-calf cows), because they have not yet calved for the second time and, neither, cows that do not become pregnant or have been discarded.

Pregnancy rate is a more efficient indicator as a management tool for monitoring reproductive efficiency. It is obtained in a short time and includes the entire herd. From deviations found in the analysis of this indicator, corrective actions can be implemented quickly to avoid the lack of calving.

The pregnancy rate is the percentage of cows that are pregnant relative to the number of eligible cows, measured at each 21-day period. Eligible cows are those that are not yet pregnant, but have already passed the voluntary waiting period, which is the time for the recovery of the reproductive system after calving, usually between 35 and 60 days.

To achieve a good pregnancy rate, it is necessary, for example, that $24 \%$ of eligible cows should be pregnant in a period of 21 days. This requires that the insemination of females in estrus be done as soon as possible, and that most of them became pregnant.

Moreover, two other indices compose the pregnancy rate: the service (or insemination) rate, which measures the percentage of cows that are inseminated in relation to the number of eligible cows in a period of 21 days, and the conception rate, which is the percentage of cows that are pregnant relative to the total number of inseminated cows. 
The service rate is basically influenced by the estrus observation and by the percentage of cows in anestrus. The conception rate is influenced by cow fertility, semen quality, and insemination process, among other factors.

The pregnancy rate measures exactly how fast the cows are getting pregnant. A very common mistake is confusing the pregnancy rate after the pregnancy diagnosis at a determined time. Indeed, sometimes it is possible to found pregnant $70 \%$ or more cows, but in fact, it is not the pregnancy rate. Sometime, the pregnancy rate is confused with the conception rate, which is very important but does not be of practical relevance, since a good conception rate with a low service rate results in low pregnancy rate.

\section{Conclusion}

By managing the reproductive efficiency of the herds through the pregnancy rate, there will be full conditions to quickly identify flaws in the process, acting in a precise and efficient manner.

\section{References}

1. Dayyani N, Karkudi K, Bakhtiari H (2013) Reproductive performance definition in dairy cattle: affective factors. Int J Adv Biol Biom Res 1(11): 1392-1396.

2. King G. Measures of reproductive performance.

3. Faria VP (1991) Estrutura atual de produção de leite no Brasil. In: NESTLÉ. 40 Curso de pecuária leiteira, ESALQ Piracicaba, pp. 19-22.

\section{Your next submission with Juniper Publishers will reach you the below assets}

- Quality Editorial service

- Swift Peer Review

- Reprints availability

- E-prints Service

- Manuscript Podcast for convenient understanding

- Global attainment for your research

- Manuscript accessibility in different formats

( Pdf, E-pub, Full Text, Audio)

- Unceasing customer service

Track the below URL for one-step submission https://juniperpublishers.com/online-submission.php 